\title{
"A(nother) Critique of Pure Reason": Toward Civic Virtue in Legal Education
}

\author{
Angela P. Harris \\ and Marjorie M. Shultz*
}

\section{INTRODUCTION}

In Patricia Williams' book, The Alchemy of Race and Rights: Diary of a Law Professor, Williams mentions "a constitutional-law exam in which students are given the lengthy text of a hate-filled polemic entitled 'How To $\mathrm{Be}$ a Jew-Nigger' and then told to use the First Amendment to defend it."1 Williams makes the point that students taking such an exam, in this case especially Jewish and African-American students, are required to write against their own personal knowledge and experience. She notes that a student who refuses to do this will receive a lower grade, and guesses that "everyone, including perhaps the students of color, will rationalize this result away as an inability to 'think like a lawyer.' "2

In this context, the phrase "thinking like a lawyer" means suppressing or denying one's feelings and personal experience while putting forth a "cold" analysis of the "facts." Classical legal education celebrates reason and devalues emotion. ${ }^{3}$ Seeking to remove legal reasoning both from "the political" and from "the personal," law professors traditionally shun openlyexpressed emotions in the classroom. When classroom discussions raise deeply emotional issues, students who are able to dispassionately discuss

- Professors of Law, University of California, Berkeley, School of Law (Boalt Hall).

1. Patricia J. Williams, The Alchemy of Race and Rights 84 (1991).

2. Id. at 82 .

3. In this article, we use "reason" and "rationality" interchangeably, and contrast them with "emotion" and "feeling," also used interchangeably. We are aware, however, that the labeling of human subjective states is a complex endeavor. Reason, rationality, thought, mind, and logic form one cluster of related terms in common parlance; emotion, feeling, passion, and sentiment form another. These clusters are also terms in the larger metaphorical structures of hard versus soft, fixed versus fluid, and male versus female.

To make talking about these issues more difficult, the terms within each matrix are not fungible. Thus, "reason" is sometimes a larger word than "rationality," used to include spiritual and emotional dimensions of experience and judgment. "Feeling" conveys lesser intensity than "passion," but also less depth. Few words transcend the dichotomy entirely, although "awareness" (which tends to connote perception rather than activity) and "wisdom" stand above the polarity to some degree.

We use "reason" and "emotion" as mutual opposites because we think this is a common-sense usage. As a normative matter, we would argue that reason properly understood should involve the interweaving of all available data, including emotions, perception, intuition, and intellect. But in practice, reason tends to be treated as the opposite of emotion. 
both sides of the argument are the ones admired. ${ }^{4}$ It follows that law professors often write examination questions asking students to address issues that touch on the most incendiary aspects of American social life, and expect them to "think like lawyers."

On the one hand, then, there is the view that nothing is objectionable about the exam Williams describes; it simply requires students to be "toughminded," an admirable goal. At an opposite extreme, it might be argued (though we do not think this is Williams' position) that the exam is outrageous and impermissible, even racist, simply because of its "inflammatory" content-because it touches on deeply emotional issues in a blunt, even heavy-handed way. We disagree with both positions, and this essay seeks to explain why.

This essay is part of a larger project in which we try to rethink the way law professors approach not only teaching but legal scholarship and faculty governance as well. We are critical of the notion that virtue in these endeavors requires that emotion be banished from them. In our experience, emotions can never successfully be eliminated from any truly important intellectual undertaking, in the law or elsewhere. Attempts to banish them succeed only in ignoring them instead, and this distorts thought. When strong emotions are considered inappropriate, participants in an intellectual exchange may miss the places where they need to think more deeply. More powerful participants may get their feelings expressed and satisfied through their control of rules and procedures, while less powerful people must suppress theirs. Or, everyone's emotions may be so stifled that the significance and meaning of an intellectual debate is entirely lost.

In our view, acknowledging the role of emotion in intellectual endeavors, including the classroom experience, can enrich debate. Our point is not that people should express their feelings for the sake of self-expression. Rather, when emotions are acknowledged and rigorously examined, they can serve as a guide to deepening intellectual inquiry; they can make participants in a debate more keenly aware of the importance-or unimportance-of an insight or dialogue. Emotions are part of thought, not its antithesis. Thus, the attempt to stifle rather than utilize them exacerbates the felt thinness and irrelevance of much discussion in the law school classroom.

In Part II of this article, we outline our tentative steps toward a theory of reason and emotion in the context of legal education. In Part III, we tell stories from our own experience to illumine how emotions and reason can enrich one another in the classroom. One of us (M.S.) is an experienced teacher, recipient of the campus Distinguished Teaching Award but continuing to learn from the challenges of the classroom; the other (A.H.) is a journeywoman, a popular teacher but still feeling her way toward a critical

4. See Roger C. Cramton, The Ordinary Religion of the Law School Classroom, 29 J. LEGAL EDuc. 247, 250 (1978) ("The law teacher must stress cognitive rationality along with 'hard' facts and 'cold' logic and 'concrete' realities. Emotion, imagination, sentiments of affection and trust, a sense of wonder or awe at the inexplicable-these soft and mushy domains of the 'tender minded' are off limits for law students and lawyers."). 
understanding of her own practices. We hope that the differences as well as similarities in our perspectives will make this section provocative reading.

\section{The Dominant Ideology of Legal Education}

In our experience, most law teachers share an ideology about the appropriate roles of rationality and feeling in the classroom. ${ }^{5}$ This ideology can be reduced to two propositions: first, that rationality and feeling are opposites, and second, that rationality is appropriate in legal reasoning whereas feeling is not. ${ }^{6}$ In accordance with this ideology, law teachers tend to treat the development of logical thinking as the central, even exclusive, focus of legal training, and they seek to suppress emotional expression in the classroom.

This ideology harms both the educational process and the understanding of legal institutions and legal thought. In this section, we first offer some speculations about the sources of and reasons for the dominant ideology. We then describe the dynamics of this ideology-how it manifests itself in the classroom and in the curriculum. Finally, we describe what we see as the politics of the dominant ideology: who or what is at stake in the process of its reproduction.

\section{A. The Sources and Function of the Dominant Ideology}

The sources of the dominant ideology are not hard to find. Law schools operate at the junction of the academy and the legal profession. Both realms tend to polarize reason and emotion and to elevate reason.

In the academy, the dichotomy between reason and emotion is linked to similar dichotomies between mind and body, "objectivity" and "subjectivity," and science and art. Emotion, the body, the subjective and personal, and the artistic are devalued in contrast with reason, the mind, the objective and neutral, and the scientific. ${ }^{7}$ Academics speak of themselves as living "the life of the mind"; and they might be described as people who are, to an unusual degree, uncomfortable with bodies, feelings, and persons, as compared to matters of intellect.

\section{M.S.: I remember a history prof I had in grad school who was enor-}

5. We use the word "ideology" here as a descriptive rather than critical term, referring to a set of ideas and practices that are followed more out of "common sense" than out of self-conscious belief.

6. We thus identify reason and emotion as a "hierarchical opposition" prevalent in the ideology of teaching. For theoretical explorations of dualisms in legal doctrine and legal reasoning more generally, see, e.g., J.M. Balkin, Deconstructive Practice and Legal Theory, 96 YALE L.J. 743, 746-47 (1987) (identifying deconstructive technique as the temporary reversal of hierarchical oppositions); Gary Peller, The Metaphysics of American Law, 73 CAL. L. REv. 1151, 1155-56 (1985) (comparing rationality and passion in legal discourse); and Pierre Schlag, Cannibal Moves: An Essay on the Metamorphoses of the Legal Distinction, 40 STAN. L. REV. 929 (1988) (noting, with some concern, the prevalence of legal scholarship that focuses on the identification and examination of such dichotomies).

7. This is a reading of the Western academic tradition that many feminist philosophers have produced, noting that the dualism is gendered as well. See, e.g., Susan Bordo, Feminist Skepticism and the 'Maleness' of Philosophy, 11 J. PHIL. 619, 622-29 (1988) (discussing the work of Helene Cixous and Luce Irigaray). 
mously knowledgeable about English legal history but for whom any human contact appeared to be acutely painful. He lectured three hours a week with his eyes fixated just one inch above the tops of students' heads. The only variation was that occasionally, for several minutes at a time, he would close his eyes entirely while he continued talking. The sad thing was there were only about fifteen doctoral students in the course. We met for approximately 100 hours during that year, but he never once made eye contact with me or anyone else.

The dichotomies of reason and emotion, subjective and objective, have powerful practical consequences in the academy. Disciplines tend to rate themselves and each other according to how closely they approximate a certain image of the scientific. "Hard" science, which is the best kind of science, is thought to be about neutrality, objectivity, empiricism, fixedness, and reproducibility-qualities which emotions lack. ${ }^{8}$ Above all, "science" stands for the absence of the personal, subjective, and individual. Because emotion is viewed as quintessentially personal, fluid, and unmeasurable, affiliation of fields or individuals with emotionality reduces their credibility and status in academic circles. ${ }^{9}$

Christopher Columbus Langdell, the father of modern legal education, drew on this science-envy in bringing legal education into the university. Langdell, the renowned popularizer of the "case" or "Socratic" method of legal education, explicitly assimilated the study of law to the practice of science. Legal reasoning, in his view, was a deductive process by which one derived right and wrong answers from principles inherent in the written opinions of appellate judges. ${ }^{10}$ His exhortations to treat law as a science had the practical effect of encouraging universities to incorporate law schools and the ideological effect of reinforcing educators' convictions that emotions were irrelevant to legal knowledge and learning. ${ }^{11}$ The notion that the study of law is and should be scientific has clung tenaciously, long after Langdell's

8. Ironically, developments in some of the "hardest" of sciences suggest that the more strenuously one searches for these qualities, the more elusive they are. In explaining the fact that the observer is inextricably part of the observed, the Heisenberg Uncertainty Principle brings physics into conversation with post-modern philosophy and alters cherished notions about the possibility of perfect objectivity. See, e.g., Frituof CaPra, The Tao of Physics: AN Exploration of the Parallels Between Modern Physics and Eastern Mysticism (1975). Thus, many academics continue to worship an image of "hard" science that is to some extent obsolete within the world of hard science itself.

9. For a discussion of the term "objective" used as an honorific and contrasted with "subjective," see Jeanne L. Schroeder, Subject: Object, 47 U. MIAMI L. REv. 1, 42 (1992) ("Really, Really True Objectivity v. Wishy-Washy Subjectivity").

10. For a discussion of Langdell's view of law as a science, see Thomas C. Grey, Langdell's Orthodoxy, 45 U. PITT. L. REv. 1 (1983). Langdell's enthusiasm for viewing the law as scientific was shared by many of his contemporaries. See Robert StEvens, LAw SchOol: Legal EduCATION IN AMERICA FROM THE 1850S TO THE 1980S 52-55 (1983).

11. On science as a passport to academic respectability, see STEVENS, supra note 10, at 51-52. Interestingly, Langdell's method was famous for being profoundly alienating to students. See 2

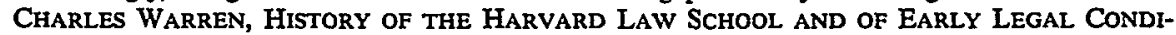
TIONS IN AMERICA 373 (1908) (reporting that "[m]ost of the classes could see nothing in his system but mental confusion and social humiliation"). Perhaps as a reaction, the image of law school as a kind of intellectual boot camp which only the "smartest" people could survive began to evolve. See STEveNS, supra note 10, at 54. 
narrow view of legal reasoning as something like geometry has been abandoned. ${ }^{12}$

The dominant ideology is also reinforced by the ideals of the legal profession. The prevailing image of the law is of blindfolded Justice balancing the scales of decision. Because lack of bias or prejudice is essential to adjudication, Justice wears a blindfold to shut out persons and passions that might inappropriately influence her inward deliberation. Even where lawyers are advocates or advisors rather than adjudicators, the profession emphasizes "thinking like a lawyer." The phrase celebrates thought that is incisively rational, logical, analytical, and, especially, dispassionate. One powerful image of the ideal lawyer is as a "hired gun," able to argue anything on behalf of anyone. ${ }^{13}$ Like the master trial lawyer making impassioned speeches to the jury, he or she can marshal emotion in others but is (ideally) untouched by her own fervor. She should at least always be capable of having a drink with the other side after the trial is over. ${ }^{14}$

Despite these roots, a dichotomy between reason and emotion may seem, from other vantage points, surprising. Similar dichotomies, notably the dichotomy between objectivity and subjectivity, are currently under attack in the academy. ${ }^{15}$ More significantly, law and legal institutions seem deeply and inevitably infused with emotion. Law legitimates official coercion. It designs institutions and processes for the resolution of conflict. It prescribes

12. See, eg., Richard A. Posner, Volume One of The Journal of Legal Studies-An Afterword, 1 J. LEGAL STUD. 437, 437 (1972) (describing the aim of the Journal as "to encourage the application of scientific methods to the study of the legal system").

13. For one statement of this view, see Murray L. Schwartz, The Professionalism and Accountability of Lawyers, 66 CAL. L. REv. 669, 672-74 (1978). For a more recent discussion of the appropriateness of the "amorality" of lawyers, see generally Stephen Pepper, The Lawyer's Amoral Ethical Role: $A$ Defense, a Problem, and Some Possibilities, 1986 AM. B. Found. REs. J. 613. Robert Post reflects on how this view both absolves the lawyer of moral blame for her actions on behalf of her clients and makes her accountable for zealous representation of the client. The public both values and loathes lawyers because of this characteristic. Robert C. Post, On the Popular Image of the Lawyer: Reflections in a Dark Glass, 75 CAL. L. REV. 379, 380, 385-86 (1987).

14. The status hierarchy within the profession also reflects the preference for rationality over emotion. The highest-paying and most prestigious jobs in the legal profession are those having the least to do with handling people and emotions and the most to do with pure intellect. Thus, appellate judges have more prestige than trial judges, and corporate lawyers have more prestige than family lawyers or tort lawyers. One study found that "fields serving 'big business' clients such as securities, corporate tax, antitrust, and banking are at the top of the prestige ranking while those serving individual clients such as divorce, landlord and tenant, debt collection, and criminal defense are at the bottom." Stewart Macaulay, Law Schools and the World Outside Their Doors II: Some Notes on Two Recent Studies of the Chicago Bar, 32 J. LEGAL Educ. 506, 509 (1982) (summarizing findings in John P. Heinz \& Edward O. Laumann, Chicago Lawyers: The Social StrucTURE OF THE BAR (1982)). Another study found that "high prestige specialties seemed to be associated with analytic skills, while low prestige specialties seemed to rely more often on interpersonal skills." American Bar Association, Law Schools aNd Professional Education: Report AND RECOMMENDATIONS OF THE SPECIAL COMMTTTEE FOR A STUDY OF LEgAL EDUCATION OF THE AMERICAN BaR Association 47 (1980) (citing F. Zemans \& V. Rosenblum, THE Making of A Public Profession ch.3). This is interesting in light of the general market phenomenon that jobs involving caring for persons and managing emotions are filled predominantly by women. See arlie Russell hochschild, The Managed Heart: Commercialization of Human FeelING app. C at 234-35 (1983).

15. See Schroeder, supra note 9, at 2 (describing the academic assault on objectivity). 
norms for conduct. It expresses and effectuates social ideals of fairness and justice. These functions-central in our society-cannot help but evoke strong emotions. Moreover, legal rules and institutions incorporate our deepest concerns about culpability and desert, free will and responsibility, equality and freedom. These ideals are generally agreed upon at the highest levels of abstraction, but their implementation is deeply problematic. Given these realities, it seems that emotion could not possibly be eliminated from the domain of the law. ${ }^{16}$

We speculate that it is precisely because of the threat unrestrained emotion poses to the "rule of law" that the dominant ideology has been so pervasive. Because law stands at the fulcrum of deeply consequential, deeply emotional, never-ending struggles, it must seek a basis for fairness and disinterest. The attempt to isolate and suppress emotion in law serves at least two purposes. First, it provides habits and aspirations that increase lawyers' ability to resist the temptations inherent in their societal function. ${ }^{17}$ Second, it increases their credibility and the legitimacy of lawyers' social role. Thus, legal institutions and professionals separate reason from emotion and exalt reason as a way of warding off a fundamental fear that law itself is inseparable from the passions of "politics." In this way, the dream of law becomes the dream of pure reason.

What begins as a useful counterbalance to real occupational tensions can, however, create dysfunction as it becomes over-extended, rigid, or self-serving. In the dominant ideology, fairness and neutrality have been encoded as "objectivity," and "objectivity" is narrowly understood as "rationality." Thus, the ideal of detached reason has become central to the legal tradition. ${ }^{18}$ As reproduced in legal education, however, this ideal of detached rationality as the epitome of "thinking like a lawyer" has become hypertrophied. Too often, the dynamics of the ideology distort and impoverish the quality of legal thought and learning. Moreover, the politics of the dom-

16. A number of commentators have made this point. See, e.g., Paul Gewirtz, Aeschylus' Law, 101 HaRv. L. Rev. 1043, 1046-50 (1988) (discussing the Greek tragedy Oresteia as illuminating the essential role of emotion within the law); Martha L. Minow \& Elizabeth V. Spelman, Passion for Justice, 10 CARDozo L. REv. 37 (1988) (discussing Justice Brennan's defense of passion as necessary to good judging and suggesting criteria for judging the quality of judicial thought).

17. The idea that professions develop coping mechanisms peculiar to the specialized pitfalls and stresses of their work has particularly been developed in the sociology of medicine. Doctors constantly faced with pain and death develop a degree of callousness that enables them to survive. See Howard S. Becker, Blanche Geer, Everett C. Hughes \& ANSElm L. STRAuss, Boys iN White: STUdENT CULTURE IN MEDICAL SChOOL (1961). However, taken too far, this callousness destroys their ability to perform their work sensitively or adequately.

18. This ideal is reflected in legal rhetoric as well as in its institutions and practices. The rhetoric of legal argumentation involves appeals to universal reason and rationality, suppression of the first-person voice in favor of the third-person voice, and suppression of the active voice in favor of the passive voice. The ideal law review article is authorless: The argument "speaks for itself," which is to say that it speaks directly to the mind of any reasonable person. Emotions, which are idiosyncratic, nonneutral, and not objective, are not found or evoked in standard legal scholarship. See Gerald B. Wetlaufer, Rhetoric and its Denial in Legal Discourse, 76 VA. L. REV. 1545, 1558-59 (1990). 
inant ideology tilt the playing field against those people with the least structural power, and against ideas that threaten the status quo.

\section{B. The Dynamics of the Dominant Ideology}

In our view, the dominant ideology about the relationship of rationality and emotion contributes directly both to the alienation and malaise of students and to the dissatisfaction of teachers with the process of legal education. The polarization of reason and emotion prevents either from enriching the other, resulting in emotion that is undisciplined, unexamined, and unowned, as well as thinking that is arid and shallow. What gets lost is not only the sense of excitement and adventure in the classroom that is briefly experienced in the first year, but also the richness of legal thought itself.

A.H.: I vividly remember my Welfare Law class when I was a law student. I loved the material and adored the teacher, yet there was a strange sense of constriction in the classroom discussion. No one ever got to speak for more than a few sentences as the professor whirled around the seating chart. He would set us up to explore the arguments on one side, then the other, but if any of us strayed from the invisible script we would be cut off and it was on to the next student. What emerged was an orderly "on the one hand ... on the other hand" discussion that made for great notes. Yet there was a sense that we were just actors reading from a preset text.

More disturbing in the end, though, were the absences. Even though we all got a chance to talk, there was a sense in which we were absent from the conversation. Miserably, every morning before class, I would go in the bathroom and throw up, anticipating that I would be called on. Partly it was performance anxiety; I was painfully shy and the class was large. Partly too, Marge now suggests, it was me literally divesting myself of my insides before going into the classroom.

It was not only we students who were absent from the class as individuals. It was also in some sense the subject itself. We talked about incentives and disincentives, George Gilder's social theories and Frank Michelman's view that welfare should be considered a right. We reviewed every argument in our teacher's typically fair- and broad-minded style. But there was still something missing. Only once did I really want to be called on, and it was the day we had to read and discuss George Gilder's ideas about welfare encouraging the pathology of itinerant black men and promiscuous, castrating black women. I wanted to speak from my own sense of anger and outrage. I wanted to talk about my own experience of living on food stamps, and I wanted to talk about the media demonization of "welfare queens" as an example of racism. But, strangely enough, that was one of the three times in the whole semester that I wasn't called on. In fact, none of the black students was called on, despite our hands in the air. It was the felt reality of welfare that was missing from the course, a sense of the human stakes of our intellectual game.

When law teachers seek to eliminate emotion from legal discourse, all they achieve is the suppression of its direct expression. Emotion that is suppressed, however, does not really disappear. Instead, it goes underground. 
Pent up, it sometimes explodes directly. "Rogue" emotions erupting far from their source reach the wrong targets, hit the wrong people, and can be a source of confusion and pain. More frequently, suppressed emotion injures the classroom experience indirectly-blocking learning, producing judgments that are based on little more than stereotypes, and creating intellectual and personal isolation. Emotion ruled of the official educational agenda remains unchallenged, unexamined, and undisciplined by reflection and analysis. Emotion made impermissible becomes emotion disowned, emotion for which no one is responsible.

A.H.: Another vivid memory from my law student days is the free-floating hostility that often swept through a classroom, particularly in the first year. No one ever missed the chance to sneer. Our class took our anger out on one student in particular-one of those people, usually white guys, who always had their hands in the air. Halfway through the quarter, people took to setting off the beepers on their digital watches whenever he spoke. Three or four times during the hour he would raise his hand, the teacher would call on him, and the beeping would begin. The student speaking would look around, bewildered, and the rest of us would mutter angrily or suppress titters. The professor tried to ignore the whole situation, which only intensified the rage welling up in us, a rage out of all proportion to its ostensible provocation. ${ }^{19}$

In retrospect, I think what was happening to us had nothing to do with that student who enraged us so. We were first-years, dismayed and terrified by the teachers, by the process, and by each other, and our response was to push back, hard, at anything and anyone who seemed vulnerable. Unexamined and unacknowledged fear turned into anger and contempt, equally unexamined and unowned. The glee that we felt when a teacher skewered a student with a brilliant display of sophistry was similarly a reflection of our desperate fear and longing for control. We felt ourselves getting ugly, and the fact that no one would or could talk about what was happening to us in any systematic way only made the process worse.

If emotions are successfully repressed, rationality suffers in any case. Draining intellectual arguments of emotion also drains them of meaning. Without guidance from emotions, many well-ordered arguments seem equally good. In common parlance, when people are trying to avoid recognizing the emotional reasons for our actions, they say they are "rationalizing." Rationalizing classroom discussion makes it dry and sterile. Rationality unchallenged by emotion makes legal analysis an abstract exercise. The result is not only boredom but legal thought that is both technically precious and practically irrelevant.

A.H.: In my criminal law class one semester, I asked students to write

19. A number of commentators have pointed to the aggression and hostility that afflicts law school classes. One of the earliest in this generation was Duncan Kennedy, How Law School Fails: $A$ Polemic, YAle Rev. L. \& Soc. Action, Spring 1970, at 71, 72-74. Kennedy's critique of anger in the classroom was answered by Alan A. Stone, Legal Education on the Couch, 85 HARV. L. Rev. 392, 407-18 (1971). A more recent example is Catherine Weiss \& Louise Melling, The Legal Education of Twenty Women, 40 STAN. L. REv. 1299, 1338-41 (1988). 
an essay in which they revamped the criminal justice system to more clearly reflect the moral justifications for punishment. I was shocked to read several essays which blandly suggested that measures like tattooing inmates with a letter or symbol representing their crime would appropriately serve goals of retribution and deterrence. I first thought these students were kidding, but they were perfectly serious. They were simply carried away by their own intellectuality into a world where there was no longer any sense of human fellow-feeling. The result was not only a lack of compassion, but ideas that would seem silly, impractical, and/or offensive to any policymaker- "ivory-tower reasoning" in the worst sense.

In legal education, one result of the dominant ideology is a classroom atmosphere that gradually alienates both students and teachers. For students, the classroom is a place where they learn to make the logical moves of "on the one hand ... on the other hand," and do so for case after case, in course after course. At the same time, the classroom becomes a potentially dangerous place, a place where emotions may get out of control, a place where people attack and are attacked. Bursts of passionate emotion occasionally interrupt the flow of abstraction in the classroom, but in the domain of rationality they seem out of place, "crazy," irrational. Ridicule (or, even more effective, nonresponse) quickly restores discipline at the hands of professor or peer, and the aberrant behavior is officially relegated to the hallway or the bedroom "where it belongs." The classroom becomes simultaneously boring and dangerous.

Personal alienation and poverty of thought are the twin results of this process. Many law students report feeling alienated and frustrated in the classroom. ${ }^{20}$ Alienation, experienced as a withdrawal of the self from the educational process, leads to the diminishment or extinction of intellectual curiosity and a transfer of energy elsewhere, into extracurricular activities or into part-time jobs. This alienation also prepares students for the more significant withdrawal of their selves from their professional identity as lawyers. Rather than seeking jobs that express their personal interests and commitments, too many are prepared to follow the crowd into the highestpaying or most prestigious job available. Not surprisingly, they feel like mere "mouthpieces" or tools of the system.

More insidiously, the quality of the students' thought is impoverished. Students coming to law from advanced study in other disciplines often remark on how intellectually shallow and uninvolving legal reasoning is. Trained to value logic and segmented linear analysis above all else, many law students are left ill-equipped to face hard choices. They learn to articulate arguments for and against, but are unable to place their arguments in a broader philosophical, moral, or practical context. When personal judgment is required, they lapse into apathy or blindly take a "cop-out" position "be-

20. For another professor's similar perceptions of law students' feelings, see Duncan Kennedy, Legal Education as Training for Hierarchy, in THE Politics of LAw: A Progressive CritiQue 40, 59-60 (David Kairys ed., 1982). 
cause that's how I feel."21 Aside from a greater facility with legal rhetoric and narrow forms of argumentation, there is little intellectual growth from the first year to the third year of law school.

The classroom similarly becomes uninteresting and alienating for the teacher. If a caricature of abstract reason becomes the goal of the educational enterprise, and if students are supposed to leave their hearts and their larger selves outside the classroom, law students will be treated as passive receptacles of knowledge. Personal experience and the light it sheds will seem irrelevant to legal thought. When teaching is simply the exercise of getting students to jump through logical hoops, day after day, week after week, it becomes mind-numbing and devoid of intellectual interest once the teacher herself knows the substantive material. This dynamic may account for the widespread lack of interest in teaching among law teachers.

M.S.: After the closing class in my first year of teaching, I returned to my office fresh from the rousing ovation my students had bestowed on me, carrying a bouquet of flowers and some joke gifts they had given to me. I was energized and flushed with pleasure at the successful completion of my first year. My office neighbor, a senior member of our faculty, was coming out his door as I arrived at mine. We exchanged pleasantries and he asked how I felt about my first year of teaching. I told him I had really enjoyed it; my excitement and satisfaction were certainly evident. He congratulated me, sharing my pleasure, and then made a comment that was a real "downer." "Enjoy it while you can," he said. "You'll never enjoy teaching as much again as you did this first time."

Meant as a form of anticipatory sympathy but functioning as professional socialization, this was only one of many remarks making clear that teaching is not (and should not be) a deeply rewarding activity to a law professor. I've thought about that comment a number of times in the intervening seventeen years. The good news is that I didn't need the sympathy. I have enjoyed teaching virtually every class I've ever taught-some far more than that first class. But the underlying message is worrisome. At first, I took my divergence from the "teaching-is-boring" norm as a signal there was something wrong or inadequate about me. Only as I matured in confidence did it begin to seem, instead, unfortunate that many spend a substantial part of their daily work life in what they see as an "inevitably" unrewarding downhill slide. They must not get the energy I do from facilitating students' increasingly complex, sophisticated and empowering understandings of legal material. And they must not experience teaching as a genuine exchange in which interaction with each new wave of students generates new substantive insights for $m e$.

Once entrenched, the practices and ideas represented by the dominant ideology tend to reproduce themselves in a vicious circle. In search of a more worthwhile classroom experience, teachers attempt to be more "rigor-

21. This pattern is likely one reason that many teachers find it so difficult to teach professional responsibility courses. By the time they have been fully trained in the dominant ideology of standard legal method, many students will intensely resist any effort to make them focus on personal ethical decisionmaking or on the emotions that are intrinsically connected with it. 
ous" and exalt the exhibition of logical, linear thought. Some ban the phrase "I feel" in the classroom in order to encourage students to deliberate rather than simply emote. Some may avoid teaching certain subjects, like rape, or even certain courses, like civil rights, in order to avoid provoking student emotion. ${ }^{22}$ But these tactics only exacerbate student alienation and further deaden the classroom experience.

Less often, the mistakes run in the other direction. Attempting to enliven class discussion, a teacher may encourage the expression of raw emotion by introducing deliberately controversial materials, only to find that the class, unpracticed at integrating emotion with reason, degenerates into chaos. Where emotion has generally been excluded, its sudden aberrational appearance will likely startle and irritate, underscoring the prevailing message that emotion is inappropriate to classroom thought.

A.H.: I remember a colleague's horror story about a civil rights seminar. The materials were designed to challenge student thinking about issues of subordination, including racism, sexism, and sexual orientation, and they carefully mixed theory pieces with first-person narratives. The teacher excitedly looked forward to a stimulating intellectual exchange. Instead, the class quickly polarized itself into factions defined by identity politics and spent the whole semester firing angry outbursts at each other and at the teacher. Intellectual activity came to a halt as everyone accused everyone else of racism, sexism, homophobia, laid claim to their own privileged sense of victimhood, and declared an unwillingness to credit anyone else with good faith.

If emotion and reason are not integrated throughout the course, the result can simply be to reinforce the split between the two.

A.H.: I recall a discussion about pedagogy at a national law teachers' meeting. One white woman described a day in her civil rights course when she asked her two black students, the only students of color in the class, to talk about what it felt like to be discriminated against. She proudly reported how "the whole class cried, even the white men," and how the experience contributed to racial tolerance and understanding. The women of color in the room looked at each other, appalled.

Quite apart from the issue of whether the students were comfortable with being asked to "testify,"23 the danger here was of using emotion-here the students' tears-as an end in itself. At the end of such a class, the black students may feel that they performed a service and the white students may feel pleased with themselves for their sensitivity, but what has anyone really learned about racism? What may have been fostered instead is the further split of emotion and rationality. In this dynamic, black students offer their

22. At our school, for example, one justification offered for teaching federalism, separation of powers, and the Commerce Clause in the first-year constitutional law course rather than equal protection or due process has been that the more interesting, involving material will "rile students up" too much before they have learned proper (unemotional) legal analysis.

23. See Kimberlé Williams Crenshaw, Foreword: Toward a Race-Conscious Pedagogy in Legal Education, 11 NAT'L. BLACK L.J. 1, 6 (1989). 
emotion and their raw experience, their suffering, for white students to intellectualize upon and theorize about. ${ }^{24}$

The dynamics of the dominant ideology thus contribute to ever shallower visions of rationality and to ever more unproductive expressions of emotion.

\section{The Politics of the Dominant Ideology}

The ideology which denigrates emotion and elevates rationality in the law school classroom also has systematic political consequences that harm students and truncate intellectual inquiry. First, the politics of the dominant ideology tend to reinforce existing hierarchies of power in the classroom. Second, these politics obscure power relations within legal thought and legal institutions, reinforcing the sense that the substantive status quo is normal, natural, and necessary.

Although individuals vary, there is some scientific as well as anecdotal support for the proposition that, on average, women are more comfortable with acknowledging and expressing their emotions in conversation than men. ${ }^{25}$ If this is true, then to the extent that emotions are banned from the classroom, women will tend to be disadvantaged as participants in debate.

Perhaps more importantly, suppressing emotion and elevating rationality in the classroom reinforces existing hierarchies of all sorts. We have already noted that legal rules and principles are both important and controversial. Existing legal rules and arrangements are not "neutral"; rather, every legal structure or decision creates "winners" and "losers." "Winners" can be comparatively dispassionate in discussing existing arrangements unless or until those arrangements are seriously threatened. "Losers," by contrast, are likely to be emotionally agitated by what they perceive as unjust disadvantage.

Given an unequal distribution of power and its consequent unequal distribution of comfort, a norm of detached reason perpetuates the dominance of "winners." It allows them to protect the status quo, arguing that their views and preferences predominate because they are more meritorious (read "more rational"). In our view, however, the causal flow runs in the other direction. Calm dispassion and relative lack of emotion is often the effect of having already won the battle. ${ }^{26}$

All too often, these tactics are destructive. A student whose premises are at odds with the prevailing premises is initially dismissed as irrelevant. If the student speaking out is a woman or a person of color, the conflict is

24. See id.

25. The linguist Deborah Tannen, for example, argues that, on the average, women converse as a way of establishing intimacy and connection, whereas men talk primarily as "a means to preserve independence and negotiate and maintain status in a hierarchical social order." DEBORAH TANNEN, You Just DON'T UNDERsTAND: WOMEN AND MEN IN CONVERSATION 77 (1990).

26. Even when parties on each side show emotion, politics may determine whose feelings are acknowledged as significant. Arlie Hochschild reports that "[h]igh-status people tend to enjoy the privilege of having their feelings noticed and considered important. The lower one's status, the more one's feelings are not noticed or treated as inconsequential." HocHSCHILD, supra note 14, at 172. 
exacerbated by a presentation that is perceived as more emotional in style than is usually permitted in the classroom. Reacting to being dismissed, as well as intensifying her criticism of the debate, the student persists. She is then ruled out for being "irrational" or "out of control." Finally, her display of emotion is perceived as a matter of personal instability or "special pleading" rather than substantive force. ${ }^{27}$ The student ends up further disempowered and the teacher further empowered by the use of the dominant ideology to deflect an intellectual challenge.

A.H.: During the "diversity wars" at Boalt, one recurrent issue was "civility." Students took over the dean's office, protested in the hallways, interrupted classes, spoke passionately at rallies and at faculty meetings. Some professors supported severe sanctions for the most boisterous students, not on substantive grounds but because the students had breached the norms of civility to which everyone in the law school community was supposed to adhere. This argument overlooked the great disparity of power between the faculty and the students. Although both sides were equally emotionally involved, the civility rules were easier for the faculty to observe because the faculty held most of the structural power.

Thus, the part of the dominant ideology that elevates rationality over emotion excludes from the conversation (in the vernacular, "silences") individuals who are used to infusing thought with feeling. It denominates their contributions "irrational," "crazy," and "unreasonable."

Yet the deepest challenges to the status quo are often motivated by and expressed with emotion. The existing distribution of power preserves the calmness of some while rendering others desperate. These consequences should worry law teachers to the extent that they subscribe to the idea that the classroom should be a level playing field, a place where traditional hierarchies of power have no place. But the dominant ideology does not simply offend egalitarian ideals; the silencing that is accomplished through elevation of reason over emotion also impairs substantive thought about the law. We like to think of the classroom as a marketplace of ideas, but we tend to miss the state intervention which tilts the market in its very formation. The silencing of people is also a silencing of ideas that challenge the status quo. The more radical an idea, the more disquieting it is to those comfortable with the status quo. If fear of emotion is a legitimate reason for curtailing conversation, the most challenging ideas are the least likely to be heard.

\section{TOWARD A New IdeOlogy of REASON AND EMOTION}

Neither banning emotion, intuition, and gut instinct in a search for "rigor" nor encouraging the expression of raw emotion in a search for mean-

27. Hochschild reports on a survey of women in public life:

These women ... were agreed on the following points. When a man expresses anger, it is deemed 'rational' or understandable anger, anger that indicates not weakness of character but deeply held conviction. When women express an equivalent degree of anger, it is more likely to be interpreted as a sign of personal instability.

Id. at 173 . 
ing will rescue the law classroom from its malaise. The fault lies in the dominant ideology itself. Rather than casting reason and emotion as opposites, we should think of them as shading into one another. Rather than placing rationality above emotion, we should think of them as co-equal. If reason and emotion are compatible and valuable dimensions of human experience, segregating feeling and elevating rationality dilutes and distorts legal thought. Part of the solution, then, is to replace the dominant ideology with one that sees reason and emotion not as mutually exclusive but as complements in the search for truth.

Reason and emotion are each rich realms of human experience. Dictionaries and common parlance tend to define the two as dichotomous, each given shape and definition by the absence of the other. But those who have thought hardest about the relation between rationality and feeling tend to see them as complementary rather than mutually exclusive, and as not so distinct from one another as might first appear.

One contemporary philosopher, Martha Nussbaum, draws on a range of thinkers to reject the hypothesis that reason and emotion are opposites. Nussbaum repudiates the view that emotions are "blind animal reactions ... in their nature unmixed with thought, undiscriminating and impervious to reasoning." 28 Instead, she asserts, research on the emotions in various disciplines points out the ways in which emotions are modified by beliefs; in fact, emotions are partly cognitive in their very structure. ${ }^{29}$ Nussbaum therefore maintains that it is sensible to view emotions as "responsive to the workings of deliberation and essential to its completion." 30

A theme of Nussbaum's work is that the abstract reasoning typical of philosophy (and, we should add, legal scholarship) can be expanded and enriched by the perceptions of great literature, one of whose characteristics is its emotive nature. Contending that acute and sustained perception of emotion is a vital dimension of human knowing, Nussbaum relies in part on Aristotle, who saw emotions as "more reliable in deliberation than detached intellectual judgments, since emotions embody some of our most deeply rooted views about what has importance, views that could easily be lost from sight during sophisticated intellectual reasoning."31

As we have already argued, there are good reasons for the dominant ideology about reason and emotion. The law needs to be fair. It should strive to eliminate prejudice and illegitimate influence, and to prevent adjudicators from acting out of narrow self-interest. The law seeks predictability and equity to ensure that like issues and disputants are treated alike over time. It requires that all relevant persons and points of view receive a respectful hearing. For these reasons, objectivity and neutrality are necessary elements of justice.

28. Martha Nussbaum, Love's Knowledge: Essays on Philosophy and Literature 40 (1990).

29. Id. at 41 .

30. Id.

31. Id. at 42. 
But idealized justice also embodies wisdom and compassion. Supreme Court justices who are publicly revered are not simply cold calculating machines of "smartness" but deeply humane people who struggle to do the right thing-to explain the Constitution in ways that reflect core values and strong feelings about equality and due process. ${ }^{32}$ Our society extols justice as blind, but also celebrates it when it is deeply seeing.

Legal education ought not to reject the conclusions of philosophers and other academics. Nor ought it to blind itself to the realities and aspirations of the lived law itself. The polarization of reason and emotion makes each a caricature of itself. In law, as in other intellectual pursuits, inductive and deductive logic are not the only form of intelligence. Hunches, intuition, and emotive perception and response all can contribute to legal thought. Rationalism drained of feeling results in action and judgment drained of motivation and meaning.

In a parallel fashion, unexamined emotion encourages chaos. If emotions truly were blind animal reactions, the desire to banish them from the classroom would be appropriate. But understood as partly constructed by and partly responsive to reason, emotion can bring energy, judgment, and fullness to thought.

The key, in our view, is to bring reason and emotion back together again, recognizing each as an indispensable element of legal thought. Allowing emotions into the official learning process yields the insights and transformations that arise from new ways of perceiving and knowing. Recognizing emotion in thought allows new forms of substantive and personal engagement, as well as meaningful ownership of assumptions and consequences. Subjecting emotions to reasoned reflection recaptures "rogue" emotions that obstruct thought and divide people. Infusing rationality with emotion gives meaning and value to logical analysis. And it renders visible the fact that, whatever its aspirations, law is never neutral.

As a philosophy of legal education, then, our view of reason and emotion as complementary elements of thought requires us not just to allow emotions into the classroom, but to learn how to examine them, learn from them, and incorporate them into rational argument. In this section, we offer some stories from our own teaching experiences to illustrate our successes and failures in trying to follow this new ideology.

\section{A. Marge's Stories: Examining Emotion}

"If you can't understand business language, you shouldn't be a businessman." The comment is delivered with an armored quality, signalling an awareness of impending confrontation. I literally feel the stiffening of rage and hurt ripple through one part of the class. Tight-lipped tension and withdrawal causes other students to slump deeper into their fixed swivel

32. Cf. KenNeTH L. Karst, Belonging to America: Equal CrTIZENSHIP AND THE CONSTrTution 233-42 (1989) (suggesting that justices should exercise empathy and compassion in their decisionmaking). 
seats, hoping for invisibility or at least anonymity. This first-year contracts discussion concerns unconscionability doctrines. The question is whether unconscionability rules should be invoked to resolve a dispute over contract interpretation in favor of a franchise operator. The franchisee is a person of color; the student commenter is white.

Issues that touch on race, gender, sexual orientation, or economic class cause many students to invoke their own personal cloture rules. I've asked about these silences both in class and out. Initially, I get a set of fairly common answers. "I learned in college that it's better to keep your mouth shut on these issues." "I don't want to be hated for the next three years." "If I said what I thought, I'd never get a date again." I know from experience that individuals who are insensitive to the social signals these students describe may well be greeted with verbal or, more likely, nonverbal expressions of outrage. That's the tension that infects my classroom now in the wake of the business-language comment. The decriers of "political correctness" are right, then, that my student was being "disciplined" by his peers for making a "politically incorrect" comment. But their explicit or implied solutions to the problem are profoundly inadequate.

Comments like the business-language remark reflect elements of a "lawas-neutral-reason" view. This view takes for granted that prevailing allocations of wealth and power are based on neutral meritocratic principles. The angry stiffening of portions of my class reflected how deeply some students questioned both that general assumption and this particular invocation of it. Moreover, while concern about the silencing of traditionalists, conservatives, or white males has legitimacy, the critics of "P.C." surrender that legitimacy if they seem not to have noticed or taken any responsibility for the silence of women and nonwhites in most academic classrooms prior to the current era. At one time and in some places, that silence resulted from the literal exclusion of women and people of color. Now, formerly excluded groups may be present but may still speak less, or less freely, than others. When they do speak, their viewpoints and experiences often raise fundamental challenges to ordinary classroom dialogue. Sometimes the resulting clash of perspectives is angry. Sometimes those who have been little heard until recently adopt the view that what's said in the classroom should be policed so that "insensitivities" like the businiess-language comment are not expressed at all.

In my judgment, the solution isn't to make certain topics or views offlimits-either those of my student commenter or those of his classmates. But neither is it to continue business-as-usual when setting the substantive agenda or when deciding how that agenda will be considered. Once discussion is broadened, traditions about what matters, what's interesting, and what's correct will all be deeply controversial. Emotion as well as reason should play an essential role in the resulting effort to integrate traditional commitments with new perspectives.

My student's "business language" comment and the varied reactions to it presented an opportunity. Discomfort is often a signal that glib generaliza- 
tions or facile reasoning are insufficient. When controversial issues surface, the stakes are raised. The session can feel like a disaster, but it can also become an astonishing success. Embracing the opportunity requires reconsideration of the dominant ideology. The standard approach would be to ignore the comment and the reactions to it as "inappropriate emotionalism." Alternatively, a professor might "discipline" the student (or the class' response) by making some sweeping criticism of his or their politics-perhaps by decrying today's political correctness in the university before quickly changing the subject. Either approach would miss the potential for learning. Learning requires examination of both the emotion-laced views of the speaker and the as-yet-unarticulated emotions of others in the class. The latter likely range from "Right on!" to "Racist, classist pig!" to "Damn, here comes all that special-pleading crap again."

To get a class deeply engaged, willing to expose preconceived notions, to question received wisdom, and to consider threatening new ideas, I have to get them to talk about what they really think and believe about whatever we're studying. I can only do that if I can be comfortable in the face of emotion, theirs and mine, and can help them to be likewise. Emotions are entwined with thought and judgment. Unless emotions can be part of the official task, the thought process can't go very deep. And if the life experiences, agendas, and beliefs of people in the classroom vary widely, emotional friction will be enmeshed in any genuinely meaningful exchange. Ignorance and inexperience combine with the release of long-suppressed anger to breed confrontation. Avoiding issues that upset students (or teachers) only contributes to shallow thought, balkanized classrooms, and a malaise born of "objectivity" run amok. The quality and generality of our knowledge as well as any genuine resolution of our personal and interpersonal tensions depends on the deep participation of many (rather than simply a few) in considering assumptions, problems, solutions, and implications.

The "businessmen" comment and its emotional fall-out produces an incendiary silence. I allow it to go on for a few seconds, marking that something significant is happening. Then, with a good-natured and purposely exaggerated sigh, I bewail my "pedagogical incompetence." "I just can't," I moan, "get it through your heads that businesspersons, like God, may well be shes rather than hes!"

Gender-neutral language is a project I emphasize consistently-one my students recognize as serious to me despite the fact that $I$ typically pursue it in a playful mode. Gender, too, is a silence-evoking topic in today's classrooms. But right then, it was race and class divisions that had paralyzed the group.

My "God may be a she" remark breaks the tension. By kidding myself as well as the student speaker on a topic that's diversionary but sufficiently related, I make plain that I understand the nature of the chill everyone is feeling, but that we're going to live through it.

After the chuckle dies away, I turn serious again with one of my minilectures. I name the tension that has seized us, exhorting the class to talk its 
way through the silence. I challenge them, "If we can't deal with issues like race and class, who can? Society is falling apart on these tensions. Lawyers are supposed to help manage intergroup conflict. We play a key role in defining such central terms as 'justice' and 'discrimination,' 'fairness' and 'blame.' We've got smart, articulate, caring people of all colors and sexes in this room. If not us, who?"

A bit shocked by my intensity and challenged by my arguments, a growing number of students start warily, sometimes angrily, to talk. They talk about how they felt when the incendiary comment was made and about where they've encountered such assertions before. They talk also-and passionately-about the law, unconscionability doctrine, poverty, racism, business standards, and justice. The discussion about why we want or don't want some people in business-and the implications of that discussion for the rules of franchise contract interpretation-is not easy. Nor does it arrive at neat conclusions. But it is deep and wide, probing and tough, meaningful and genuine.

When such discussions start, nervously and tentatively, a framework of trust is a condition of their transformation into full and intense interchange. I have to have created a safe space in which we can discuss the topics of race and class, topics that today's students have learned to see as impossibly scary. Safety can't stem from a retreat to doctrine abstracted from life, or from reason that scorns feeling. Nor can it be an easy mouthing of politically correct sentiments that fails to challenge assumptions and implications, comprehensiveness and coherence.

Trust in the classroom is built on uncompromising respect for each individual. I have to want to know what each student really thinks, feels, and has experienced. I have to show that our conversation matters. Leavening our reasoned analysis with intuition and empathy, with purposes and values, enables us to move beyond mere comprehension toward wisdom. Submitting feelings to reflection allows some choice about which feelings to reinforce as worthy and which to try to discard. Occasionally, with luck, the class actually experiences that the more we engage, the better our substantive understanding and more vital our community.

Heated discussion about businessmen and business language may seem unusual because contracts is generally considered an unemotional, "nonpolitical" subject matter. Controversial issues in contracts are less visible than those in rape doctrine or civil rights law, but, as in all legal material, vital issues are embedded within its rules and principles. Once one starts noticing, many contracts issues cry out for both reason- and emotion-based analysis.

A woman struggles over whether any single shared meaning can exist to resolve interpretation questions. She raises the example of date rape (does "No" mean "Yes"?) and applies the question to interpretation of leases.... A man argues against enforcement of surrogacy contracts because it constrains his sense of family values. ... Others strive to discern the implications of Ian Ayres' article showing a correlation between new car prices and 
the race and sex of the buyer: ${ }^{33}$ Are Ayres' data grounds for per se unconscionability? We review Bob Gordon's attempts to upend traditional assumptions about the role of the legal system in a contract for dance lessons. ${ }^{34}$ We consider whether Gordon's article itself is sexist in characterizing a middle aged woman as pathetically lonely. ${ }^{35} \ldots$ Others grapple with Pat Williams' ruminations about whether defending consumers on the theory of unconscionability is worth the loss of their self-esteem entailed by claiming they're incompetent, stupid, weak, or desperate. ${ }^{36}$ Students are tense as they try to discern how they (and their future clients) can act with dignity. I ponder aloud the thought that damages remedies that say nothing at all about gender may nevertheless reinforce traditional patterns by which men's market work is valued while women's nonmarket labor in the home is officially devalued.

Each of these topics is emotionally and intellectually tough. Engagement with the entire range of judgment, reason, feeling, and intuition about them can yield payoffs that are not simply interpersonal, pluralist, or democratic, but also hard-headedly substantive.

The demand for dispassionate rationality doesn't just inhibit discussion of volatile topics. It also blocks insights that can flow from other modes of perception.

Impaled by my second repeated, "But why?," the student squirms, then finally offers a desperate "I don't know. It's just sort of my gut instinct." The sophisticates in the class cast each other knowing looks, smugly superior to this naif who trespasses the law's religion of reason. They confidently expect me, sometimes known on the student grapevine as "Ms. Kingsfield," to skewer this hapless soul-albeit politely. I sense the disappointment of some and the relief of others as, instead, I launch into what's become a yearly event, my "rap" on the subject of "gut instinct."

I have a number of these five-minute minilectures. Some spontaneous, some a regular feature, these reflections play an important role in my classroom.

Instead of a slash-and-burn attack or a cool put-down of the student's "gut instinct" explanation, I expand on a considered theme. I lay out my conviction that such feelings are significant albeit insufficient. "They must be disciplined, challenged," I urge. "Often they will end up counterbalanced, complexified, sometimes even disregarded. But just as frequently they are helpful to insight-pointing the way to an as-yet-unseen issue, cautioning that an analysis is somehow incomplete and that linear rational thought may not yet have captured all the relevant elements of the equation."

33. Ian Ayres, Fair Driving: Gender and Race Discrimination in Retail Car Negotiations, 104 HARV. L. REV. 817 (1991).

34. Robert W. Gordon, Unfreezing Legal Reality: Critical Approaches to Law, 15 FLA. ST. U.

L. REV. 195 (1987).

35. Id. at 205.

36. Patricia J. Williams, Alchemical Notes: Reconstructing Ideals from Deconstructed Rights,

22 HARV. C.R.-C.L. L. REv. 401, 419-20 \& n.54 (1987). 
There is usually no immediate payoff. Sometimes no gold mine ever emerges from this maneuver. But a seed has been planted. And sometimes-when invited to open more channels of awareness-students challenge the class with a dramatic new way of thinking about an issue.

A woman in my law and medicine seminar makes the common feminist analysis that women should not be constrained in their reproductive decisionmaking by the interference of boyfriends, husbands, or fathers. Driven by obviously intense emotion, a student named Ed utters an expletive and throws up his hands. I wait a second then probe, "Say more." Acknowledging that he has not yet figured out where his feelings come from or how valid they are, Ed elaborates his point rather slowly at first. Eventually, he gets out his sense that women these days are asserting their right to sole decisionmaking authority regarding abortion, fetal tissue transplant, frozen embryos, methods of childbirth, donor insemination, and so forth. He is beginning to feel, he says, that men are being treated as means to further women's reproductive ends! The heavily female class is nearly stunned to silence. Then everyone starts talking at once.

Ed's comment was a clear example of "gut instinct" as thought in motion. He had not articulated this idea even to himself before this moment. But it had been gathering in him for awhile, and he experienced it first as impatient, explosive anger. His demonstrably emotive and controversial remark kicked off one of the most productive and vibrant discussions of the semester. Some students were angry, and many were unconvinced, but most everybody reexamined the issues. My norm that emotion can be shown allowed Ed's initial outburst. My complementary commitment to examining roots and implications made it possible for Ed to trace his meaning, to challenge others, and to shake up some of the calcified givens of gender debate.

Such incidents happen more than occasionally. Another student, initially moved by a sharp but inchoate sense of unfairness, tripped off a scintillating exchange about the assumptions underlying Western concepts of property. She questioned why the owner-as opposed to the painter or the expert providing the certification-should be entitled to the increase in value resulting from identification of a painting as the work of a master artist. Another student asked why necessity should count as a defense when it can be described as a personal aberration but not when it arises from systematic social circumstances. Her own economically deprived background made her original critique both penetrating and heated.

Students may experience surprise when reason and emotion are integrated, not polarized. They sometimes comment explicitly on how my teaching style differs from prevailing ideas and previous experiences. One student observed that, even in a large class of 130 students, "discussion flowed as easily as conversation in a living room." Another observed, "It's weird. You're both the most intimidating and the most accessible professor I've ever had." When the learning environment combines the feeling and informality that typify a living room with the structure and rigor of a classroom, students may be startled. The fact that a professor can be simultane- 
ously intimidating and accessible is puzzling-but often invigorating-to students accustomed to the dominant ideology.

Not all emotions that come into view have to do with the issues surrounding political correctness. Many are more individual and personal. Competition, anxiety, arrogance, and timidity are other powerful feelings that play important roles in law school.

The student I've just called on is clearly "blanking out" or "freezing up." After being asked to present the case, he pores over his book and the silence stretches uncomfortably.

I've learned to tolerate silence. Fifteen seconds feels like an eternity, but it's not, and the wait often produces unexpected payoffs. The "frozen" student's tension was important not just for him, but for everyone in the room. Many were experiencing intense responses: "There but for the grace of God ..."; "How can he be so inadequate?"; and "If that happened to me, I'd never open my mouth again!" Whatever I do has consequences affecting an array of issues-the class' respect for persons, its norms about preparation, and the likelihood of its taking intellectual risk.

Rather than pressing and humiliating, or moving on to call on someone else, leaving this student ashamed and the class demoralized, I talk for a few minutes about "what we're about."

"Law isn't like multiplication tables you can memorize in order to 'perform," " I tell the tension-filled group. "The demand to talk extemporaneously about questions that aren't easily predictable is tough and tense. I know that. But it can also be deeply instructive, especially with reference to 'thinking on your feet.' " I express my view that, rather than recitation-asindividual-finished-product, our ideas are part of a giant collective editing process. They will be amended, adjusted, abandoned, enlarged as we go along. The process of turning ideas and facts around like a mental kaleidoscope allows us to see how pieces rearrange themselves into different patterns with the slightest change of perspective and characterization.

To get past the tension of perceived personal "failure," I draw on this group's shared experience, using myself to provide permission to make mistakes or to fail to know. I mention a recent instance where $I$ didn't know the answer to a question that was asked by a student in this very class, and describe my own inner thoughts and feelings on that occasion. "Panic: I don't know the answer. They'll think I'm dumb. . . . Urgent need for escape: Tell them I'll look it up and get back to them next class. . . . A desire to be a wise and appropriate role model: Admit that I'm not sure and then go on, trying to think the question through, trusting myself, piecing out at least a partial answer one step at a time. ... In other words," I say, "Just what I'm expecting you to do." The sigh of relief is almost audible.

These comments are not an invitation to laziness. I am uncompromising about my demand for preparation. In the words of one of my most cherished teachers, "I make it both necessary and profitable to be prepared."37

37. In a seminar on teaching, Mel Eisenberg responded this way to a question about how he got students to prepare. 
The student's frozenness was not a lack of preparation. Most first year students are so eager that teaching them feels like trying to restrain thoroughbreds at the racetrack. If anything, the problem in first-year classes is the performance anxiety that afflicts so many high achievers. The goal is to create a setting where their minds can flow as fluidly as possible.

Enabling students to see thought as process rather than as product produces big payoffs. It encourages them to stretch themselves, to learn to endure short-term failure in pursuit of greater long-term depth. My comments also remove the blocked student from the spotlight, giving him a chance to catch his breath, check the book, and get himself together. They allow the student who has "clutched" to feel less shamed and conspicuous. When I return to the substantive question, more often than not I get an intelligent answer-avoiding the twin disasters of soft evasion and harsh humiliation. Because I've acknowledged what's really happening emotionally, and have made it permissible by identifying with it in a concrete, self-revealing way, the moment turns into a substantive and emotional success-a win/win situation for us all.

As the weeks move along, freezing up is less of an issue, but competitiveness, envy, and peer group antagonisms become more prominent problems in classroom dynamics. Airtime is a scarce resource in a class of 130 eager first-years. Trying to get quality as well as democracy is a real challenge. Many students view participation as useful and necessary; some even experience it as exhilarating. Others are ecstatic if they can avoid ever speaking. Some are quite critical of those who talk a lot.

I see the bored and mocking there-he-goes-again looks spread across the class as John raises his hand for the third time this hour and for the umpteenth time this semester. I figure the "turkey bingo" players in the back row will be calculating their winnings again.

It's time for some more norm setting. Again my strategy is to make visible the emotional facts, trying to seize an educational benefit. Not calling on anyone yet, I comment, "There's obviously a range of acceptable preferences regarding speaking time. I want to spread the opportunity to those who don't 'fire' quite so fast." After reassuring the fast talkers that they are important contributors to our collective discussion, I continue, "We'll learn things that we'd otherwise miss from people who're a bit quieter or slower to talk."

Explanation provided, I then invoke my personal cloture rule: "If you've talked twice or more in the last week, you can't talk during class for awhile, until further notice."

The following week I'll silence an additional layer of talkers, along with this week's most speedy speakers. Acknowledging the emotions involved in silence and speech within the classroom, I'm striving for improved substance as well as better group process. There'll be some pauses, but the discussion will widen. It's illuminating for students to actually experience that. I often comment further when I invoke the second layer of cloture:

"In most settings, speech and airtime are distributed in ways that reflect 
prevailing habits and hierarchies. Altering those patterns broadens the substance and quality of the input. White males represent only about $35 \%$ of this classroom population, but in an 'unregulated' environment, they tend to do two-thirds of the talking. 38

"That doesn't mean guys are ill-intentioned, or that they shouldn't speak. It just means that some 'regulation' of airtime is useful." Letting them know that I'm not the humorless man-hater that some associate with raising of these issues, I close with a grin and the observation that I'm the doting mother of two white males, the sister, daughter, and wife of others."

The amazing thing is that this works. Those who have to reduce their talking continue good-naturedly to participate; they simply raise more questions after class. No one has ever complained. A number of people have gone out of their way to express their appreciation. Moreover, without such mild regulation, I would not have gotten some provocative discussions that emerged from individuals who are not the "fast guns." For example, an African-American woman once sparked a lively class session when she said that, from the standpoint of traditional consideration doctrine, contract law seems to dismiss everything that women are, value, and typically do as "nothing." An intense interchange about whether damages rules governing breach of employment contracts unfairly favor employers' interests over those of employees was also the product of a fairly reticent student's observation. I might not have been as interestingly challenged regarding my use of the term "ghetto" in a discussion on consumer unconscionability if a Jewish student whose family came from Eastern Europe hadn't spoken up.

Sometimes it's not simple airtime but stereotypes about each other that keep classes from getting deeper than the surface.

I sense rather than see that my co-teacher is horrified as I open a session of my legal ethics seminar by recounting that my husband and I had a major fight while watching $L . A$. Law the night before. I continue anyway. I tell the class that only after the fight did I realize that the content of the showbias against people considered unattractive by conventional standardsmade my husband and me unusually anxious, causing us to explode our tension at each other on an apparently unrelated topic during the show's commercial break.

After telling that story to the class, I point out a problem that has been alternately paralyzing and embittering this class' discussions for several weeks. Students expecting to work for public interest organizations often

38. Suzanne Homer and Lois Schwartz found in their study of Boalt students that "a majority of women and people of color indicated that they never asked questions or volunteered answers in class, in contrast to nearly two-thirds of white males who stated that they had done both with some frequency." Suzanne Homer \& Lois Schwartz, Admitted but Not Accepted: Outsiders Take an Inside Look at Law School, 5 BERKELEY WOMEN's L.J. 1, 29 (1989-1990). For similar observations about women's silence in the classroom, see, e.g., Taunya Lovell Banks, Gender Bias in the Classroom, $38 \mathrm{~J}$. LEGAL EDUC. 137, 139-40 (1988); Stephanie M. Wildman, The Question of Silence: Techniques to Ensure Full Class Participation, 38 J. Legal Educ. 147 (1988); and Project, Gender, Legal Education, and the Legal Profession: An Empirical Study of Stanford Law Students and Graduates, 40 STAN. L. REv, 1209, 1239 (1988). Studies outside the law school context have found that men talk more than women in a variety of public settings. See, e.g., TANNEN, supra note 25 , at 75-76. 
see students going to work for corporate firms as "sleazes" and "sellouts." The compliment is returned in the form of caricatures about "knee-jerk, bleeding heart liberals." At issue are not simply hurt feelings but the quality of the group's analysis of the subject matter.

Using my own life and feelings to unblock the class' logjam was an inspiration of the moment. It caught their attention; it modelled self-examination and ownership of feelings. Most important, it got people to look at how their own inner tensions about professional roles were causing them to fight rather than think in response to their classmates' arguments and insights. Stereotyping and treating people as two-dimensional cartoon figures is often a substitute for thought. Unless a teacher can break through these barriers, the quality of work suffers. Almost always the barriers combine thought and feeling, and sometimes it's me rather than a student that sets off the problem.

The class freezes as if it has just taken a collective breath and is holding it. My mind races back over the question I just asked. While hopefully provocative, it hardly seems to warrant the tension that's now obvious in this class of thirty-some 1Ls just two weeks into second semester contracts. Trying to locate the source of the evident strain, my puzzled gaze comes to rest on the student I just called on. To my immediate right at the large square seminar table, an Asian-American woman boldly leans forward, her whisper hissing in the silence, "His name's Rodriguez, not Martinez."

My outward reaction, "Oh, sorry," reflects my still-clueless state. Sensing the continuing tension, I grasp for safety by commenting that I learn names by using them, hoping people will tolerate and correct my errors until we get to know each other. The discussion continues, but the disturbance remains, undermining the ease and energy that were there a moment before.

After class, passing the Coke machine opposite the cafeteria, I come across Mr. Rodriguez and apologize again for calling him by the wrong name. We chat for a moment. Then, he offers, "Earlier today in crim law, the prof. recognized me, calling me 'Mr. Hernandez.' Hernandez was the name of the defendant in the murder case we were discussing." "Ouch," I say aloud, muttering something not entirely coherent about seeing why the class had frozen up.

Coming into class the next day, I begin by telling the group how tense and blocked things seemed after my gaffe. I report that I learned of the crim law incident after class. Although I'm nervous, I want us to talk about it. I don't want to institutionalize the tightness from the last class. For the next fifteen minutes, we struggle about stereotypes and their meaning to individuals trapped in them. I mention the natural pull toward generalization, its utility and even necessity in thought and social organization. But I talk, too, about stereotypes' capacity to wound, particularly in the context of race in America.

The class talks about feelings. A Chicana says she had been far less angry at the crim law teacher than at me. "How could you," she challenges. "You of all people." I know she means that mine was a special betrayal because I'm reputed to be "sensitive" about diversity issues. We speak of the humanness of mistakes, about the pervasiveness of racial stereotyping. I speak, too, about the oppressiveness for me and other professors of students' 
tendency to make authority figures into cardboard people, monolithic "good guys" or "bad guys" rather than real people.

Together the class and I conclude that each of us is a product and a partial captive of our own experience. No one is going to be error-free. What is important is what we do with ourselves and with each other when we step in the minefields of pain. After about fifteen minutes, we breathe a partial sigh of relief. More wary than before my naming error, but much better than before we aired it out, we continue our discussion of the law.

Falling through emotional thin ice is terribly scary. But when we can examine what has been said and done in the classroom community, calling upon the eyes and hearts of all the various participants, we can go forwardalmost regardless of what has transpired.

\section{B. Angela's Stories: Risk-Taking and the Search for Substance}

One experience that has stuck with me from when I was a law student is the day I answered a question in contracts class and my professor, somewhat bemused by my response, told me that I "spoke in poetry." At the time, I took the comment as a criticism, to the effect that literary thinking had no usefulness in law. But the longer I thought about it, the more the phrase struck me as an interesting insight.

Poetic language is dense, heavy with meaning; it tries to reduce some of the "noise" and redundancies that everyday language carries. In this sense, speaking in poetry is not so different from speaking law. Legal language at its best is also dense with meaning. In the sense that every word is potentially important, law professors teach students to read statutes as if they were poetry.

But an important distinction between poetic language and legal language has to do with ambiguity. Poetry, like puns and other forms of wordplay, deliberately increases the ambiguity inherent in all language. In this sense, poetic and legal language are at odds. Legal language seeks clarity and univocality, not the shifting multiplicity of poetry.

Yet, even though we strive for one meaning when using legal language, those who tend to speak and think in poetry can contribute to legal reasoning. Ambiguity is prized in poetry because it makes language rich in meaning. An ambiguous statement in the law school classroom can be interrogated, its potential meanings drawn out and examined. One of the skills of lawyering is to use ambiguity as fuel to move an argument in this or that direction. If nowhere else, an awareness of ambiguity's potential is useful for taking law school exams, which require students to explore as many twists and turns as possible. Ambiguity alone is unclarity; ambiguity expressed, examined, and analyzed can help deepen an inquiry.

As a teacher, I habitually repeat student comments in other words, in part to make the students feel heard but in part also to bring out the ambiguity in their statements. I try to faithfully reproduce even the false starts and to parse out the different possible meanings each remark contains. My stu- 
dents praise me for restating their comments to make them sound "smarter than they are." I think I've just gotten sensitized to the point where I take every sincere comment, however seemingly obscure, as potential poetry.

Sometimes the problem is not too much complexity and ambiguity, but too little. My students often come to criminal law either proprosecutor or prodefendant, a commitment that is deeply felt and rooted in their life histories. The danger here is that, left unchallenged, these strong feelings will block empathy for the other side. It is easy to move through the course either railing against the state or demanding justice on behalf of innocent victims. What makes the course more difficult, but in my view more interesting, is to respect the hard choices of philosophy and public policy that lie just beneath the surface of criminal law doctrine.

One of my practices is to require students to act both as prosecutors and as public defenders as they work on problems over the course of the semester. The point is not just to teach students to make arguments for either side, but to encourage them to enter imaginatively into each role. It is hard to remain completely distant from one's assigned persona when working with other students on a hypothetical case. As prosecutors, students find themselves asking for harsh punishment, not out of a simple desire to beat up defendants but out of anger and sorrow for the victim. As public defenders, they push in the opposite direction, not to beat the system but out of compassion for the defendant and anger at a system which can only add pain. My hope is that, after having imagined themselves in each role, it will be harder to reduce either side to a caricature.

Openly acknowledging emotions can also help sharpen students' awareness of the tensions between reason and emotion incorporated into the criminal justice system itself.

My criminal law class is usually full of people who would be pejoratively described as "bleeding heart liberals," and this year is no exception. Today we are discussing People v. Wolff, 39 a case about a mentally disturbed boy who murders his mother. In its opinion, the California Supreme Court reduces the boy's first-degree murder conviction to second-degree on the grounds that he lacked the maturity and mental capacity to fully appreciate the gravity of his actions. As usual, the description of his preposterous thought processes makes people giggle and then feel uneasy about their mirth. But there is another strange emotional dynamic today. We talk about whether the court was properly within its discretion in changing the jury's verdict based on a new legal principle, but the students' concern seems to be elsewhere.

They note that the court committed the boy to a hospital for the criminally insane. "How easy is it to get released from a place like that?" someone asks. I talk about criminal and civil commitment. "Maybe a firstdegree murder conviction would have been more appropriate-you can get life without parole," says someone else. Others nod their heads. It appears

39. 61 Cal.2d 795, 394 P.2d 959, 40 Cal. Rptr. 271 (1964). 
that the major concern in the class is with making sure that this boy is incapacitated for as long as possible.

Another student raises her hand. 'Isn't this whole discussion at odds with the way we started the class out?" she asks. She reminds us that when we started the course with moral justifications for punishment, the prevailing sentiment was to criticize incapacitation as a goal as both practically imprecise and morally questionable. Where are my bleeding heart liberals now? "What happened?" I ask.

People look sheepish. Finally, someone says simply, "But these people are scary!"

Sometimes the tensions between reason and emotion are right at the surface of the material.

My course materials include a newspaper editorial about Robert Alton Harris, recently put to death by the State of California. The editorial describes Harris' deprived childhood and the many ways in which he never got a chance in life, and asks how we can hold such a person blameworthy. After reading the editorial, many students argue that Harris was not a person deserving of blame and should not have received the death penalty. The day after this discussion, I read to them a detailed description of his crime from a published report of the case-how he killed two boys, and later laughed while he ate one victim's hamburger. The class is silent while I read the account and for a long moment after. Then it erupts. Now many students feel Harris deserved to die and are happy he did. I remind them of the opposite prevailing view the day before, and we struggle with the dual character of this killer as both victim and victimizer.

The struggle to bring emotion and reason together is particularly vivid in any discussion of retribution. Is retribution simply rationalized vengeance? If it does represent a form of vengeance, is there anything wrong with that? Is a desire for vengeance after someone has been badly hurt a wrong feeling? Is it a permissible feeling as long as it is not expressed in public policy? Or is it a feeling that, when shared by a jury of the defendant's peers, helps bind the shattered community back together again? These issues, requiring us to come face to face with strong emotions, are part of the substance of criminal law itself.

The ways in which emotional content is expressed in law are sometimes more subtle, locked into stereotypes, assumptions, and even into rules.

We read a case and materials suggesting that white collar criminals are consistently given a break in sentencing, and usually someone comments that we don't even use the same language to describe white collar criminals and street criminals. The people who robbed the country during the recent savings and loan debacle are not legally guilty of robbery, even though their economic impact on all of us may be greater than that of the drug addict who robs the nearby Seven-Eleven. During this discussion, much of the class will argue that white collar crime should be more severely punished than street crime when its effects are more pervasive. We talk about whether the distinction between "white collar" and "street" crime is itself formed and strengthened by race and social class distinctions. 
Later in the course, however, as we read materials about self-defense against home invasion, students speak thoughtfully and movingly about the fear that burglary evokes, the ways in which one's house is an extension of one's body, and how a burglary is therefore like a physical violation. Here I remind the class of our earlier discussion and ask whether people still feel that the distinction between street crime and white collar crime is unjustified. Again the question arises: Is it appropriate to tailor public policy to our own fears, even when those fears may reinforce harmful stereotypes? 40

The acknowledgement and examination of emotion, as part of a general attempt to engage in legal conversations with whole rather than truncated selves, makes the discussion harder; but it also makes it more compelling, more compassionate, and more real.

Most of our stories so far in this essay illustrate the recognition and management of emotions evoked by the subject matter of the course or by the dynamics of law school class discussion. But perhaps the most difficult situation requiring the integration of emotions and reason is when the teacher herself comes under fire.

A student approaches me after my civil rights class one day. It has been a lively, emotional discussion about interracial dating. But towards the end of the class, this student, an "out" lesbian, raised her hand and remarked that the whole hour had been spent assuming universal heterosexuality. I agreed that, although we had been very aware of the inseparability of gender and race in our discussion, we had ignored the politics of sexual orientation which clearly ran through the issues we were talking about.

Now the student and I chat further. I thank her for making her point, feeling disappointed with myself-why did it have to fall, as usual, to the disempowered to educate the privileged? But after pushing me to include more material about sexual orientation in the class, she pushes me in an unexpected direction. "Maybe you could say something in your opening lecture tomorrow about what you thought of the discussion," she says. "We want to hear more about how you feel." This idea fills me with dread.

Part of the reason for this reaction is simply that $I$ am a reserved person. Where Marge might occasionally use something like a fight with her husband the right before to help students realize the extent to which emotions can serve as a marker for a buried intellectual problem or conflict, I am attached to the notion of a strict line between "public" and "private" life. But another reason why I feel hesitant to open up in the classroom has to do with a felt sense of vulnerability which is not just personal, but structural.

Pondering my civil rights student's comment, I remember the semester I taught my normally enjoyable first-year criminal law class at Stanford. The tension in the class had been obvious from the very beginning. We started by talking about moral justifications for punishment. In the midst of discussing whether and to what extent the existence of systemic subordination should alter our judgments about retribution, a woman passionately pointed

40. I also include in my materials an excerpt from Stephen Carter's article, When Victims Happen to Be Black, 97 Y ALE L.J. 420 (1988). Here the issue is more difficult to talk about, because it is racialized. Is there a widespread stereotype of black men as criminal predators? To the extent that black men sometimes victimize others, can they also be considered victims? 
out that violent criminals are mostly male and attributed this to "the pathology of masculinity." Some of the men in the class were clearly hurt and offended by this comment, so I started class the next day by making a little speech about how our task as a community was to simultaneously struggle to express our own thoughts and feelings honestly while respecting the thoughts and feelings of others. "Amen," said one of the men. We laughed. Everyone seemed relieved, and we plunged in again.

But something else was clearly wrong. Two students in the class, one a white man and one a white woman, challenged me day after day-questioning my facts, misunderstanding my points, clearly feeling uncomfortable and clearly holding me responsible. When I talked to the woman in my office, she freely admitted that she "hated" my class. She didn't like the way I sought to present criminal law as having no firm answers and as being inextricably intertwined with larger social issues of race, class, and gender. "If I wanted to take a sociology class, I would have gone to graduate school," she said.

The anonymous midterm student evaluations showed a wider dissatisfaction. The majority of the students were pleased and said so, but a significant minority were deeply unhappy. "She talks too much about race. This is not an Afro-American studies class," declared one student. Other comments accused me of being too feminist, too political, and generally not "legal" enough. Still other comments went to my teaching itself. "She doesn't control the class well" showed up several times.

When a class goes sour, the management of emotion faces its ultimate test. Part of the challenge is dealing with one's own ego.

I commiserate with a colleague over dinner. She is also teaching a firstyear class. "I've got these four frat guys who sit at the back of the room," she says. "They sit there and sneer at me the whole hour. I know they hate me. Everybody else in the class loves me. They think I'm the best teacher they've ever had. But all I can think about when I walk into the classroom are those four guys!"

Here, one mistake is collapsing in the face of criticism, ignoring the majority who are pleased or tolerant and accepting the assessment of the "four guys" as reality. Another is becoming defensive and dismissing all criticism as mere carping. Both mistakes involve the failure to unpack and examine emotion-those of the students and the teacher-under the light of reason. I wanted to learn from the criticism without taking it as a judgment of my personal or professional worth, and to engage the students in a conversation that would be productive rather than destructive. To do this required me to analyze the emotions swirling around the classroom instead of reacting to them. But this time, the challenge was just too great.

In my office, I agonized. Should I acknowledge the tension that was now apparently widespread, or should I pretend it didn't exist? Too afraid to precipitate an explosion at a strange school, I acted as if nothing was wrong until the last day of class, when I made a few wry remarks about Stanford students' reputation for being hostile to visitors. I later found that my 
course had been the catalyst for an angry and racially polarized student brouhaha about the meaning and value of faculty diversity.

The task is not only to trace the source of one's own fear and anger, but to trace that of the students' anxiety as well. Unusually angry and hostile criticisms may signal deep-seated intellectual disagreement. What is the proper subject matter of the course? What should count as "legal" materials and issues and what as "sociological," to be excluded? To what extent are race and gender oppression part of the criminal law, and to what extent do they lie beyond its ambit? What is the best way to run a class discussion? These are serious questions about which reasonable people can and do disagree.

But criticisms that are particularly vituperative and angry can also signal that more is at stake than the style or subject matter of the course. A teacher can serve as a lightning rod for anxieties that go beyond her own performance. How much of the problem was me, and how much of it was anxieties that went far beyond me, "unowned" emotion swirling until it found a target? A dialogue between teacher and student that did not shrink from emotional openness could have helped make clear what was really at stake. Instead, "what really happened" remains obscure.

I think what finally disabled me from successfully following the ideals we have outlined in this essay-from examining my students' emotions and my own-were the politics of power. As the teacher, I had lots of power over the students: the power to determine the subject matter and the style of the class, and ultimately the power to assign a grade. But the politics of the classroom are inseparable from the politics of the law school more generally; I was also untenured and a visitor. Nor are the politics of the classroom in the end separate from those of the greater society; I was also a young African-American woman. In the end, I did not feel safe enough myself to help my students feel safe from me, and an opportunity for both sides to learn from each other was lost.

My experience suggests a qualification to our thesis that the recognition and examination of emotions in the classroom can contribute to the enrichment of legal education. Patricia Williams, an African-American woman, tells the story of going to look for an apartment in New York City along with her friend, Peter Gabel, a white man. Gabel successfully secured an apartment by turning over "a $\$ 900$ deposit in cash, with no lease, no exchange of keys, and no receipt, to strangers with whom he had no ties other than a few moments of pleasant conversation. He said he didn't need to sign a lease because it imposed too much formality."41 Meanwhile, Williams writes, "In my rush to show good faith and trustworthiness, I signed a detailed, lengthily negotiated, finely printed lease firmly establishing me as the ideal arm's-length transactor."42

Williams asserts that both she and Gabel wanted to establish trust and

41. Williams, supra note 1 , at 146.

42. Id. at 147. 
closeness with the apartment owners. She explains the difference in personal styles as connected to social power. For Gabel, avoiding using his power "as white or male or lawyer authority figure"43 was a way to establish trust; closeness could be achieved by breaking down walls. For Williams, the problem was breaking down the assumption that as a black woman she was very likely "unreliable, untrustworthy, hostile, angry, powerless, irrational, and probably destitute." 44 Thus, trust was to be achieved by more formality, not less: "[T] show that I can speak the language of lease is my way of enhancing trust of me in my business affairs." 45

Similarly, the ideal of acknowledging and examining emotions in the law school classroom may be hard to achieve until a certain level of safety and trust has already been established; and racial and sexual politics deeply threaten both individual and group safety. Trust and open debate are harder to achieve in criminal law than in contracts, and harder in civil rights than in either. Similarly, the ideal of acknowledging and examining emotions in the law school classroom may be hard to achieve until a certain level of safety and trust has already been established; and racial and sexual politics deeply threaten both individual and group safety. When the teacher feels disempowered, her last resort may be distance and formality. This strategy may buy respect, but at the expense of honesty and depth. And so my Boalt student's plea, "Give us more of yourself," stays with me, an open question.

\section{CONCLUSION}

When we decided to use Pat Williams' story about the First Amendment exam as an opening, ${ }^{46}$ we spent some time discussing whether we could see ourselves assigning such an exam. We decided we could-if we modified it to offer all the students an equal challenge. Williams makes us notice that the playing field for the evaluative exercise she describes is not a level one. Students of all races and religions may reject the views in the hate circular, but Jewish and African-American students will have to contend with far more pain. Instead of targeting only two groups, then, we would ask students to imagine a pamphlet that said the worst things possible to and about them, whoever they were, and then ask them to defend that pamphlet. Even that adaptation is imperfect in that it is unable to adjust for the fact that some groups have been subjugated while others have not.

We also decided we would have to allow extra time. In our conception, a good answer would not just work through the relevant doctrine, suppressing the emotions of distaste and loathing evoked by the problem. Instead, we would want our students first to run through the doctrinal arguments protecting the pamphlet and then to address the moral implications for society and for themselves of making such arguments. Academic lawyers tend to

43. Id.

44. Id.

45. Id.

46. See note 1 supra and accompanying text. 
treat the First Amendment as morally unproblematic, as a touchstone of liberty and justice. But what kinds of personal turmoil must the attorney endure defending such ideas? And what kind of society elevates the expression of abstract principle while dismissing the injuries caused by such an "exercise of free speech"? ${ }^{47}$ The exam Williams describes, adapted to meet the concerns we identify, could open students not just to take on the role of First Amendment defender, but to critically examine that role and the moral implications of the doctrine itself.

We have two final thoughts. First, at this point in the essay, the reader may object that, given the politics of the law school classroom, our suggested ideal of acknowledging and encouraging the expression of emotion and "whole selves" in legal education is a dangerous one. The argument is this: Encouraging students to bring their whole selves, emotions included, into the classroom makes them that much more vulnerable to injury. At the same time, dropping the ideal of pure rationality removes the protection from coercion provided by a commitment to avoid both the personal and the political. The result will be either chaotic conflict or the imposition of "politically correct" (or incorrect, depending on the persons involved) views by the majority on the minority, or by the teacher on the students.

Our answer is that, in our judgment, the risk of injury (although it certainly exists) is outweighed by the potential benefits of truly engaged, passionate, and rich intellectual debate. Moreover, in our view the coercion of debate already occurs. In terms of student-student interaction, "silencing" happens whether emotions are acknowledged and expressed or not. In terms of teacher-student interaction, the teacher's regulation of what is relevant and what is not, what constitutes reasoned debate and what is simply "political" or "personal," may be experienced by the teacher as neutral and obvious but by students as both nonobvious and coercive.

Instead of attempting to suppress emotions, convictions that are "too political," and the teacher's own views, the teacher should make clear both as an announced norm and as a practice that neither the degree to which a conviction is emotion-laden nor the identity of its holder is an index of its correctness. Emotions, and opinions fusing emotions and reason, may change from day to day; and people have the capacity to persuade one another. The teacher should model the notion of truth as provisional by showing herself to be always open to persuasion, no matter how strongly her views are expressed. 48 The possibility of truth arising through free, reasoned, but open debate rather than through revelation is one of the core

47. For efforts to take these injuries seriously, see Charles R. Lawrence III, If He Hollers Let Him Go: Regulating Racist Speech on Campus, 1990 Duxe L.J. 431; and Mari J. Matsuda, Public Response to Racist Speech: Considering the Victim's Story, 87 Mich. L. REv. 2320 (1989).

48. This argument is consistent with our belief that truth is found through the aggregation and interaction of multiple perspectives. See, e.g., Sandra HaRding, Feminism \& MeTHOdology 9 (1987); Katharine T. Bartlett, Feminist Legal Methods, 103 HARV. L. REv. 829 (1990) (discussing "positionality"). Jeanne Schroeder argues that Bartlett and Harding disagree on the possibility of objectivity. See Schroeder, supra note 9, at 46-47. We will present a fuller discussion of epistemology and its relationship to our view of reason and emotion in a later work. 
ideas in our history and society. When this notion is illustrated in practice as well as announced in theory, it can reduce the risk of silencing and other injury.

Finally, the view we have taken of emotion as a component of thought indicates that negative emotions are not always the sign of failure. Rather, they can be the cost of classroom free speech. Emotions such as anger, we have argued, often signal the presence of intellectual disagreement at a very deep level. If this is the case, then we should not expect our students always to be happy, with each other or with us. Good teaching is not necessarily synonymous with happy students; and unhappy students do not necessarily mean that something has gone wrong in the classroom. ${ }^{49}$ In the end, the ideal of integrating emotions and reason in the law school classroom may lead us to more sophisticated and interesting ways of evaluating what happens in the classroom. It may also reinforce for students and teachers alike the realization that open debate sometimes means "living with dissensus." 50

We have argued that the separation of reason and emotion, and the elevation of reason over emotion, is both artificial and detrimental to the quality of legal thought in the classroom. The fear that mindless passions will overwhelm legal institutions has caused an overvaluation of abstract rationality. Our ideal is neither reason nor emotion alone, but rather a wisdom and sense of justice that integrates both. The classroom is a place where students learn both about the substance of the law and about their potential roles as legal actors. If we as law teachers can help students toward the discipline of tempering reason with feeling and feeling with thought, we can contribute both to better and wiser laws and to people of "virtue"s1 to implement them.

49. Richard Abel argues:

First, law faculties have become much more diverse in terms of gender, race, sexual orientation, and political perspective during the last twenty-five years. Second, legal education requires students to question their most fundamental values. This volatile combination ensures that student reactions to teachers will be highly charged and personal.

Richard Abel, Evaluating Evaluations: How Should Law Schools Judge Teaching? 40 J. Legal EDuc. 407, 451 (1990). For these reasons, Abel urges that student evaluations of teaching be more qualitative than quantitative. Id. For a similar view outside law teaching, see BELl Hooks, TALKING BACK: THINKING FEMINIST, THINKING BLACK 53 (1989) ("I began to see that courses that work to shift paradigms, to change consciousness, cannot necessarily be experienced immediately as fun or positive or safe and this was not a worthwhile criteria [sic] to use in evaluation.").

50. Professor Paulette Caldwell at NYU School of Law has advocated the importance of this concept in private conversation.

51. See Robin West, Relativism, Objectivity, and Law, 99 YALE L.J. 1473, 1501-02 (1990) (reviewing BARBARA H. SMITH, CONTINGENCIES OF VALUE (1988)) (calling for richer conceptions of judicial and legal virtue). 
